DOI: $10.17951 /$ lrp.2019.38.1.113-129

\title{
MirosŁaW GrusiewicZ
}

Wydział Pedagogiki i Psychologii UMCS

ORCID - 0000-0002-1717-2445

\section{EDUKACJA MUZYCZNA - W STRONĘ WSPÓŁCZESNEJ KULTURY}

\begin{abstract}
Streszczenie: Artykuł porusza kluczowe dla oświaty zagadnienie aktualności oferty edukacyjnej, kompatybilności szkoły ze światem społecznym, nauki, kultury i sztuki, w tym przede wszystkim zwraca uwagę na konieczność uwzględniania w edukacji muzycznej zmian jakie zachodzą we współczesnej kulturze. Zaprezentowane tezy i wnioski opierają się na przeświadczeniu, że obecna transformacja kulturowa jest zjawiskiem trwałym. Dokonała się one głównie za sprawą nowoczesnych technologii, mediów i powinnością szkoły i edukacji muzycznej jest uwzględnianie tego faktu zarówno na poziomie koncepcji, programów nauczania, jak i codziennej praktyki. Tekst składa się z dwóch części. W pierwszej, na podstawie analiz z zakresu teorii, socjologii, antropologii i pedagogiki kultury, omówione są elementy, które wydają się kluczowe dla zrozumienia współczesnej sytuacji kultury oraz dla planowania nowych rozwiązań w powszechnej edukacji muzycznej, w tym autor stara się zmierzyć z pewnymi stereotypami i uprzedzeniami w myśleniu o współczesnej kulturze muzycznej. Analiza tych uwarunkowań jest punktem wyjścia do naszkicowania w części drugiej zmian jakie są konieczne w edukacji muzycznej, tak aby mogła ona zaspokajać ważne potrzeby ludzi i mogła realizować istotne cele jakie jej przypisujemy.
\end{abstract}

słowa kluczowe: współczesna kultura, sztuka, sztuka muzyczna, edukacja, edukacja muzyczna

\section{WPROWADZENIE}

Powszechna edukacja muzyczna w Polsce od szeregu lat jest w stanie kryzysu tożsamości, jak i w kryzysie organizacyjno-systemowym (por. Białkowski 2000, s. 124-131; 2001, s. 179-184). Od 40 lat opiera się ona na stworzonej pod kierownictwem Marii Przychodzińskiej w latach 70. ubiegłego wieku tzw. polskiej koncepcji wychowania muzycznego. Realizowała ona postulaty edukacji estetycznej i zrów- 
noważonego nauczania, nawiązywała do ówczesnych praktyk na świecie, posiadała głębokie uzasadnienie teoretyczne. Jej głównym postulatem i celem nauczania było zrozumienie dzieł muzyki artystycznej, wywołanie u uczniów doznań estetycznych, a drogą do tego miały być różnorodne kontakty z muzyką (por. Przychodzińska 2011a, s. 4-14; 2011b, s. 4-16). Autorzy koncepcji zakładali pewną selektywność w realizacji form i treści, ale w praktyce opartej o rozbudowane podręczniki uczeń pobieżnie realizował wiele różnych treści. Obecnie, poprzez ograniczenia godzin zajęć muzycznych, wybiórczość i powierzchowność nauczania przybrały na sile. I tak prowadzona edukacja nie przynosi pożądanych rezultatów.

Drugim poważnym mankamentem obecnej edukacji muzycznej jest nieuwzględnianie w programach współczesnej kultury. Jeżeli nawet o niej się mówi, to jest jednym z wielu tematów, a współczesność traktuje się jako zbiór opisanych, skatalogowanych eksponatów umiejscowionych w pracowni muzycznej. Edukacja muzyczna nie odnosi się do współczesnej kultury, do jej istoty i właściwości, jej głębokich przemian obecnie zachodzących.

Głównym celem artykułu jest przedstawienie koniecznych zmian w edukacji muzycznej, jakie powinny nastąpić, żeby edukacja ta spełniała pokładane oczekiwania. Dla planowania nowych rozwiązań w powszechnej edukacji muzycznej niezbędnym wydaje się naszkicowanie obrazu współczesnej kultury. Jest to o tyle ważne, że edukacja powinna być głęboko osadzona we współczesnych realiach społecznych i kulturowych. W pierwszej części tekstu na podstawie analiz z zakresu teorii, socjologii, antropologii i pedagogiki kultury, omawiamy elementy, które wydają się nam kluczowe dla zrozumienia współczesnej sytuacji kultury oraz dla planowania nowych rozwiązań w powszechnej edukacji muzycznej, w tym staramy się zmierzyć z pewnymi stereotypami i uprzedzeniami w myśleniu o współczesnej kulturze muzycznej. Analiza tych uwarunkowań jest punktem wyjścia do naszkicowania w części drugiej zmian jakie są konieczne w edukacji muzycznej, tak aby mogła ona zaspokajać ważne potrzeby ludzi i mogła realizować istotne cele jakie jej przypisujemy.

\section{WSPÓŁCZESNA KULTURA I SZTUKA}

Już w latach 60. XX wieku Marshall McLuhan (1962, patrz również McLuhan 2017) zapowiadał koniec pewnej epoki w rozwoju ludzkości i co za tym idzie ogromne przemiany kulturowe. Ze znaczą dozą pewności można stwierdzić, że epoka, którą McLuhan nazywał pisma, druku, humanizmu zakończyła się, dobiegła końca. Żyjemy obecnie w epoce obrazu. Słowo drukowane przestało być podstawowym nośnikiem informacji, jest nim obraz, najczęściej ruchomy, połączony z dźwię- 
kiem. Ma to głębokie konsekwencje w obszarze całej naszej cywilizacji. Zapisane słowo jest surową myślą, którą w różny sposób można interpretować, odnosić się do niej, polemizować z jej znaczeniem. Obraz z dźwiękiem i czytaną treścią ma silne zabarwienie emocjonalne. Nie jest to informacja, jest to interpretacja informacji. Obraz ma też to do siebie, iż nie zmusza do myślenia, on bezwiednie do nas dochodzi, jest znakiem a nie symbolem. Być może książka (słowo pisane, drukowane) pozostanie ważnym nośnikiem literackich dzieł sztuki, ale już nie podstawowym źródłem informacji dla ogółu społeczeństwa. Wypieranie słowa drukowanego na rzecz obrazu radykalnie zmienia umysłowość człowieka i jego postrzeganie siebie i świata. Jako ludzie chyba coraz miej różne fakty racjonalnie analizujemy, a swoje działania w coraz szerszym zakresie opieramy na emocjach (por. Postman 2006).

Paradoksem współczesnej kultury jest fakt - że na skutek ekspansji nowoczesnych technologii, w wielu zakresach wracamy do epoki oralnej, bezpośredniego poznania. McLuhan z nadzieją patrzył na świat mediów opartych na obrazie. Zarzucał drukowi linearność i rozczłonkowanie świata na tysiące znaczeń i pojęć. Uważał, że wielozmysłowe poznanie da człowiekowi poczucie uczestniczenia we wspólnocie. I niewątpliwie współczesne media umożliwiają kontakt między ludźmi na niespotykaną wcześniej skalę i czynią go niezmiernie łatwym i powszechnym, ale i w wielu wypadkach stwarzają też pozory tworzenia wspólnotowości.

Współczesność to nie tylko świat obrazu, multimediów, interaktywnych mediów cyfrowych, to także świat urządzeń, które coraz częściej wyręczają człowieka. Rozwój technologii znacznie wyprzedził opisywany przez Neila Postmana (2004) „technopol”, chociaż główne jego myśli są aktualne - to technika teraz „myśli” za ludzi i triumfuje nad kulturą. Zaprogramowane urządzenia, podejmują nie tylko decyzje, ale zgodnie z nimi realizują je. Technologizacja w sposób znaczący zmienia człowieka, stajemy się coraz mniej odpowiedzialni za siebie i za innych.

Współczesność często jeszcze definiuje się mianem ponowoczesności, której podstawą jest postmodernizm. Zygmunt Bauman do opisania współczesnej kultury wprowadził termin „płynnej nowoczesności”. W swojej pracy (Bauman 2008) z wielką uważnością, wnikliwością i wrażliwością wyjaśnia mechanizmy współczesności. W podobnym tonie wypowiada się również Barbara Smoleńska-Zielińska (2018, s. 4-12). W wielu kwestiach podzielając zdanie obu autorów, stawiamy śmiałą tezę, że postmodernizm jest już zjawiskiem historycznym, ale o trwałych konsekwencjach, tzn. przeszedł on już do historii, był schyłkowym elementem epoki humanizmu, chociaż ponowoczesny styl życia z jego kulturowymi manifestacjami doświadczamy. Czyli, nasze kontakty z kulturą symboliczną cechuje epizodyczność i niekonsekwencja, „wielkie narracje” w sztuce ustąpiły miejsca utylitarnym wartościom, dominuje zasada przyjemności realizowana 
poprzez konsumpcję, doświadczamy kryzysu tradycyjnych wartości i autorytetów (por. Bauman 2006, s. 789-802).

Przyjęcie stanowiska, że postmodernizm jest zjawiskiem historycznym, wskazuje jednocześnie, że inne czynniki zdominowały nasze życie. I naszym zdaniem jest to zjawisko, które określa się mianem Kultury 2.0 (patrz: Bendyk i in. 2007). Nowoczesne technologie, portale społecznościowe wywierają obecnie największy wpływ na przemiany na świecie, na styl naszego życia, uczestnictwo w kulturze.

Kultura 2.0 całkowicie zmieniła relacje między nadawcą a odbiorcą informacji. Nadawanie komunikatów, w tym o przesłaniu kulturowym, przestało być domeną nielicznych, większość ludzi jest w tym obszarze aktywna. Głosy wybitnych uczonych, artystów, muzyków giną w zalewie innych. Kultura 2.0 pogłębiła - i to w sposób niebywale silny - spadek znaczenia autorytetów, przyczyniła do tego, iż słowo i same elity zyskały pejoratywne zabarwienie. Grupy ludzkie, środowiska społeczne tworzone doraźnie, stały się samowystarczalne. Dla przeciętnego człowieka opinie ekspertów często są zbyt skomplikowane i wieloznaczne, woli wytłumaczenia proste i czytelne. Kultura 2.0 wprowadziła też przesyt, wielość informacji (w tym nadmiar muzyki), do których bardzo łatwo jest dotrzeć, co powoduje pewien chaos, zagubienie człowieka we współczesności. Konsekwencją tego jest przybierający na sile populizm oraz spadek znaczenia badań, ekspertyz, głosu uczonych i krytyków sztyki.

Elementem najczęściej opisywanym, omawianym i analizowanym w kontekście współczesnych przemian jest globalizacja kultury. Barbara Jedlewska (2009, s. 13-18.) zwraca uwagę, iż jej skutkiem jest pozorne uczestnictwo w kulturze i powszechny konsumpcjonizm. Benjamin Barber (2013), podkreśla fakt, że tworzy ona proces zagrażający wolności, zaś Bożena Majerek (2018), podkreśla, że jest źródłem niepewności, zagubienia człowieka.

Z punktu widzenia praktyki edukacyjnej chyba jednak najważniejszą konsekwencją globalizacji jest to, że stanowi ona formę narzucania kultury. Człowiek przestał tworzyć kulturę, ona jest jemu przypisywana odgórnie, w jednorodnej postaci jest dystrybuowana po całym świecie. Kultura i sztuka kiedyś jednoczyła ludzi. Ona stwarzała wspólnoty, gromadziła nas pod wspólnymi wartościami, teraz jak w państwie totalitarnym są one narzucane. Rodzi się pytanie, czy jesteśmy wstanie budować poczucie wspólnotowości ze wszystkimi ludźmi na świecie, bez stworzenia silnych więzi z najbliższymi nam osobami, z rodziną, społecznością lokalną, narodową. Pytanie wydaje się retoryczne. Pomysłem aktualnie rządzących w Polsce jest próba narzucenia pewnych norm, standardów i wartości które miałyby kształtować kulturę narodową, ale rodzi się kolejne pytanie, czy w dobie obecnych przemian, tymi metodami osiągnie się zamierzone cele?

Opisane powyżej uwarunkowania kulturowe, współczesna rzeczywistości z jej zasygnalizowanymi właściwościami powoduje, iż człowiek czuje się zagubiony, 
traci poczucie tożsamości i bezpieczeństwa, co też generuje różne skrajne postawy, w tym nacjonalizmy, akceptację dla totalitaryzmów, przemocy. Doświadczamy tego i w Polsce. Jest pewna akceptacja ludzi dla działań obecnego rządu, który chociażby w zakresie polityki kulturalnej odchodzi od wzorców państwa demokratycznego na rzecz wzorców kultury państwa autorytarnego. Polityka kulturalna traci charakter wolnościowy. Czynniki państwowe oceniają sztukę przez pryzmat partyjnej polityki. Pewnym artefaktom nadaje się charakter charyzmy społecznej, powszechny rezonans, nimb wyjątkowości, a inne umniejsza się i pomija.

Wraz ze zmianą kultury, zmienia się też model uczestnictwa w kulturze. Pomijamy tutaj analizy tych zjawisk, one są powszechnie dostępne. W swoich pracach czynią to dość dogłębnie Dzierżymir Jankowski (2006), Janusz Gajda (2006, 2008), czy też Barbara Fatyga (2009; 2014). Warto tu tylko zwrócić uwagę, iż tradycyjne podziały na uczestnictwo twórczo-aktywne oraz bierno-percepcyjne tracą na znaczeniu, tak jak i stosowane wskaźniki i mierniki. Coraz częstszym w badaniach staje się podział między domowym (za pośrednictwem mediów) i pozadomowym (instytucjonalnym) udziałem w kulturze (patrz. Badanie segmentacyjne uczestników kultury 2016).

Opisane głębokie przemiany społeczno-kulturowe i technologiczne mają swoje przełożenie na sztukę w wymiarze konkretnych artefaktów oraz jej funkcjonowania w sferze publicznej. Jej właściwościom poświęcamy nieco uwagi, gdyż tak jak na wstępie zaznaczyliśmy, powszechna edukacja muzyczna w głównej mierze powinna opierać się na współczesnej sztuce muzycznej, powinna uwzględniać jej właściwości i cechy. Edukacja w umysłach uczniów powinna porządkować współczesność, czynić ją zrozumiałą i przyjazną.

W analizach ogólnych współczesnej kultury muzycznej - nie tylko w sferze publicystycznej - często porusza się problem dominacji muzyki popularnej, rozrywkowej nad artystyczną. Oczywiście trudno tu mówić o dychotomicznym podziale. Muzyka w swojej wielości znaczeń, funkcji, wartości tworzy kontinuum. Niemniej podział na te dwa zasadnicze gatunki nie wynika z subiektywnych odczuć, to są dwa odrębne światy muzyczne oparte o zupełnie inne zasady konstrukcji muzycznej i inne idee (patrz. Grusiewicz 2017a, s. 27-44). I tę dominację, zarówno $\mathrm{w}$ formie fizycznego bytu, ilości dostępnych nagrań, można przynajmniej szacunkowo policzyć, jak i można zbadać obecność danej muzyki w świadomości społecznej. Antropologia kultury przynajmniej stara się tymi problemami zajmować. Krzysztof Moraczewski (2017, por. również 2007) podczas wykładu otwierającego I Ogólnopolską Konferencję dla Nauczycieli Muzyki Szkół Powszechnych w Radziejowicach twierdził, że współcześnie muzyka artystyczna stanowi około 3\% wszelkiej dostępnej na świecie, ale twierdził też, że zawsze tak było, i w każdej kulturze dominuje muzyka codzienności i te proporcje nie są szokujące, nie są niczym nadzwyczajnym. 
Problemem jest to, iż obecnie nie potrafimy korzystać z tych kilku procent muzyki artystycznej - właściwie, zgodnie z przeznaczeniem odbierać, estetycznie przeżywać. Szersze wypowiedzi na ten temat można znaleźć w tekście Zapomniane przeżycie estetyczne (Grusiewicz 2017a s. 27-44), ale podobne myśli są udziałem wielu osób i są one wypowiadane od szeregu lat. Już sto lat temu Oswald Spengler pisał:

Pewnego dnia ostatni portret Rembrandta i ostatni takt muzyki Mozarta przestaną istnieć - chociaż może pozostać pokolorowane płótno i karta z nutami - ponieważ zniknie ostatnie oko i ostatnie ucho zdolne do odbioru ich treści (Spengler 1921, s. 168).

W podobnym tonie wypowiada się Dzierżymir Jankowski. Pisze on, że

Uczestnictwo większości ludzi w kulturze charakteryzuje się dziś jednoczesną partycypacją w różnych poziomach kultury: i tej niskiej, popularnej i tej wysokiej, elitarnej. O jakości procesu recepcji nie decyduje jednak „fizyczne” uczestnictwo (kontakt z dobrami kultury), ale zdolność recypanta do refleksji, krytycyzmu, partnerskiego dialogu, współkreowania sytuacji recepcyjnej czy twórczej (Jankowski 2006, s. 70).

$\mathrm{Na}$ te same problemy zwracają uwagę Nikolaus Harnoncourt (1995), Zofia Konaszkiewicz (1995) czy Roger Scruton (2010, s. 108 ), który zadaje pytanie:

Czy sztuka może istnieć w epoce, w której zanikły tradycje smaku, kiedy oczy i uszy są nieustannie bombardowane bodźcami, kiedy ludzkie życie jest wprawione $\mathrm{w}$ tak szybki ruch, że chwile kontemplacji prawie nie istnieją?

Ewidentną cechą współczesnej sztuki jest brak jej trwałości - doraźność. Obecnie twórcy muzyczni nawet nie deklarują, albo też bardzo sporadycznie manifestują potrzebę pisania dzieł wiekopomnych, dla przyszłych pokoleń, o trwałych wartościach. O tym problemie już ponad 40 lat temu Krzysztof Teodor Toeplitz pisał:

Dążenie zaś do dzieła wiecznotrwałego, a więc dzieła doskonałego w swojej skończoności, było dążeniem na tyle powszechnym, że literatura pozostawiła nam niezliczoną ilość portretów artystów, trawiących życie i siły nad stworzeniem jednego dzieła, czy też raczej arcydzieła, mającego zapewnić im nieśmiertelność. Znane powiedzenie „ars longa - vita brevis" oddaje w skrócie owo mistyczne nastawienie, w którego myśl ofiara uczyniona $\mathrm{z}$ krótkiego życia na rzecz nieprzemijającego dzieła nie wydawała się ofiarą zbyt wygórowaną. I oto przymierzając te kryteria do działalności twórczej w czasach nam współczesnych, a zwłaszcza do tej działalności, która łączy się ze 
sztuką i kulturą pop, odnajdziemy dzisiaj nie bez zdziwienia omal że całkowite ich zaprzeczenie (Toeplitz 1975, 14-15).

Współczesność znacznie pogłębiła tę cechę sztuki. Po części to efekt filozoficznych myśli postmodernizmu, ale głównie nowych mediów. Milionową oglądalność można uzyskać po kilku tygodniach, a może i dniach. To dla wielu artystów daje poczucia spełnienia. Kiedyś całe życie człowiek musiał pracować, aby tyle osób mogło doświadczyć jego działa.

W czasach współczesnych niezmiernie trudno jest artyście funkcjonować bez publiczności, ona daje mu nie tylko poczucie wartości i sensu pracy, ale i zabezpiecza jego życie materialnie. I przy obecnym zalewie sztuki muzycznej pierwszoplanowym zadaniem artysty staje się wyróżnienie z tłumu, bycie z jednej strony innym od innych, oryginalnym, $\mathrm{z}$ drugiej strony bycie takim jakim oczekuje tego publiczność. Przestaje być ważne to co artysta ma do powiedzenia, liczy się to co słuchacz chce usłyszeć i zobaczyć. Tak też we współczesnej sztuce muzycznej pierwszoplanowa staje się medialność przekazu, atrakcyjność wizualna - w świecie muzyki dominującą formą przekazu są bajecznie kolorowe wideoklipy i tworzone $\mathrm{z}$ rozmachem wielkie widowiska.

Obecnie sztuka bez atrakcyjnego wizerunku ma niewielkie szanse na dostrzeżenie. I jeżeli chcemy, aby wartościowa muzyka była zauważona i traktowana jako pełnowartościowy produkt też musi spełniać określone normy i standardy. Oczywiście nie chodzi tu o migające światełka, barwne dekoracje, epatowanie seksualnością, czy tworzenie wielkich widowisk. Ale muzyka artystyczna powinna mieć dopasowaną do przekazu muzycznego, ciekawą oprawę, brzmieć w pięknych salach, w interesujących scenografiach. Z dźwiękiem powinien współgrać obraz, choćby bardzo ascetyczny, ale świadomie dopasowany, współtworzący atmosferę sali i muzyki. I na te zagadnienia coraz mocniej zwraca się uwagę. Powstają na świecie i w Polsce bardzo ciekawe urbanistycznie miejsca do wykonywania muzyki, a instytucje organizujące koncerty coraz większą wagę przywiązują nie tylko do wykonywanej muzyki, ale również do jej ciekawej formy prezentacji. Problem dostrzegli również artyści. Wykonawcy muzyki z ambicjami, $\mathrm{z}$ aspiracjami przekazywania ważnych treści, na wzór muzyków z kręgu pop kultury zaczęli tworzyć swoje wizerunki i dbać o nie na scenie i poza nią. Jako przykłady takich działań można podać pianistkę Yuja Wang, skrzypaczkę Lindsey Stirling, czy z polskich muzyków Leszka Możdżera, Aleksandra Dębicza.

Znakiem obecnego czasu jest mieszanie się sztuki wysokiej z niską. W dyskursie publicznym nawet w można spotkać głosy mówiące o tym, że podziały na sztukę wysoką i niską czy też elitarną i masową są wymysłem uczonych, którzy chcą zdegradować ogromną część współczesnego dorobku. Tego typu myślenie dość 
dobrze oddaje tytuł jednego z artykułów zamieszczonych w Internecie: Kultura masowa a kultura popularna. Po wielu latach opozycja kultury niskiej i kultury wysokiej odchodzi do lamusa. W takim razie co nam pozostaje? (Leszczyński html). Niewątpliwie tego typu dyskusje i poglądy świadczą o tym, iż nie wszyscy dostrzegają różnice między wartościami artystycznymi różnych dzieł, co nie znaczy że ich nie ma. W zakresie tego problemu bliski mi jest pogląd Grzegorza Dziamskiego, który pisze:

Wiele osób uważa, że podział na sztukę wysoką i niską należy już do przeszłości, że ponowoczesność skutecznie go zatarła i wymazała. Chciałbym tu przeciwstawić temu poglądowi tezę, że podział sztuki na wysoką i niską istniał zawsze, a ponowoczesność zmieniła jedynie stosunek do sztuki niskiej (Dziamski 2017, s. 7).

Zasygnalizowany podział nie jest tylko wynikiem odmiennych funkcji pełnionych przez różne formy, gatunki i dane dzieła sztuki, w naszym wypadku utwory muzyczne, ale wynika on z odrębnych zasad konstrukcji utworu, $\mathrm{z}$ innych wartości artystycznych. Podział na muzykę artystyczną a rozrywkową jest obiektywny, chociaż w dniu dzisiejszym jest on dość często świadomie zacieramy przez samych twórców. Zaliczani do grona „poważnych”, klasycznie wyszkoleni, wrażliwi kompozytorzy i wykonawcy, w celu zgromadzenia publiczności, dotarcia do słuchaczy, nawet jak chcą coś ważnego nam przekazać, często ubierają to w lżejszą formę, sięgają po utwory z muzyki popularnej, przygotowują i wykonują aranżacje znanych piosenek, które nabierają form i znaczeń przynależnych muzyce artystycznej. Jako przykład można podać opracowania duetu Brooklyn Duo'. I odwrotnie, artyści muzyki rozrywkowej przybierają pozy muzyki znaczącej i artystycznej. W zasadzie cała twórczość Piotra Rubika, skrzypaczki Lindsey Stirling, czy zespołu Amadeus Electric Quartet hołduje zasadom pozorowania pewnych wartości i znaczeń.

Temat współczesnej kultury i sztuki tylko sygnalizujemy, wiele spraw pomijamy, jak chociażby dostępność do ogromnych zasobów muzycznych - co nota bene nie jest wykorzystywane w edukacji muzycznej - nie analizujemy i nie odnosimy się do współczesnych kryteriów wartości sztuki. Skupiliśmy się na kilku, naszym zdaniem najistotniejszych dla edukacji cechach współczesności.

${ }^{1}$ Np. Brooklyn Duo at Carnegie Hall, aranżacja piosenki zespołu A-ha Take on me, https:// www.youtube.com/watch?v=DHbLuIxw3y4 [dostęp 26.06.2018]. 


\section{OBECNA SZKOŁA I POWSZECHNA EDUKACJA MUZYCZNA}

Wyżej zaprezentowany szkic o współczesnej kulturze i sztuce był niezbędny, gdyż w naszym przekonaniu szkoła powinna być przede wszystkim miejscem praktyk i poznawania współczesnej kultury. Pisząc „współczesnej” mamy też na myśli naszą tradycję, kompozytorów i ich dzieła $\mathrm{z}$ minionych epok, które w różnych przejawach są dziś obecne, są elementem współczesnego pejzażu kulturowego. I tak też one powinny być odbierane w szkole, nie jako zabytek muzealny, ale jako istotny element współczesnej kultury.

W ostatnich latach wielokrotnie wyrażałem pogląd, że bez zasadniczych zmian i reform edukacyjnych w całej oświacie, w niewielkim zakresie możemy cokolwiek poprawić w edukacji muzycznej (patrz: Grusiewicz 2015, s. 13-25; 2017a, s. 27-44; 2017b, s. 4-9; 2018, s. 13-24). Środowisko nauczycieli i pedagogów muzyki wspólnie z pedagogami innych specjalności powinno zaangażować się w całościowe zmiany w oświacie. W najmniejszym wymiarze tych zmian nie przynosi i nie przybliża do nich ostatnia reforma szkolnictwa, nie rozwiązuje ona istotnych problemów. Tworzona w oderwaniu od rzeczywistych potrzeb społecznych, wyzwań współczesności, konserwuje stary ład. I niewątpliwie będzie ona w przyszłości czynnikiem utrudniającym wprowadzanie zmian merytorycznych w edukacji.

Szkoła potrzebuje głębokich zmian i nie dlatego, że przez prawie ostatnich 30 lat źle ona funkcjonowała, ale współczesność wymaga zupełnie innej szkoły. Czas najwyższy odejść od modelu szkoły herbartowskiej, na rzecz szkoły o jakiej mówi i pisze Ken Robinson (2015 oraz wykłady TED i inne dostępne w Internecie), szkoły rozwijającej indywidualnie każdego ucznia, jego pasje i zainteresowania, ale i wychowującej w duchu współpracy, solidaryzmu, kształtującej wspólnotowość, szkoły jako miejsca kultury. Edukacja powinna być kreatywna i twórcza, i takich ludzi powinna kształtować. Pewnym wzorem w Polsce może tu być szkoła z Konstancina-Jeziorny, która w roku 2018 wygrała konkurs Edumission na najlepszą szkołę na świecie².

W tym kontekście rodzi się pytanie, jaka powinna być edukacja muzyczna? Bez wątpienia znacznie powinna się zmienić. Po pierwsze i co najważniejsze o czym już wspominaliśmy - powinna być osadzona we współczesnej kulturze, nawiązywać do współczesnych form i współczesnego przekazu muzyki. Współczesna kultura muzyczna powinna być punktem odniesienia, centrum działania. Nauczyciel przede wszystkim powinien być przewodnikiem po współczesności - znać współczesne realia, wykorzystywać współczesne technologie.

\footnotetext{
${ }^{2}$ Szkoła No Bell z Konstancina-Jeziorny, patrz: http://www.nobell.edu.pl/ [dostęp 26.06.2018].
} 
Przez całe dziesięciolecia wiele autorytetów, w tym Maria Przychodzińska, Barbara Smoleńska-Zielińska, Wiesława Sacher w swojej działalności i pracy dydaktyczno-naukowej zabiegały o to, aby kultura humanistyczna, świat z poprzedniej epoki był żywy i aktualny. Osobiście uważam, iż te postulaty przedawniły się, kultura się zmieniła, tego świata już nie ma. Trzeba szukać we współczesnej kulturze (której częścią jest cała nasza tradycja, w tym tradycja muzyki kultury europejskiej) wartości piękna, dobra i prawdy. W tym kontekście, nasza orientacja do treści szkolnego nauczania powinna się zmienić i dotyczy to nie tylko muzyki, ale i całego bloku przedmiotów humanistyczno-artystycznych.

Drugim koniecznym zabiegiem jest redukcja obowiązkowych treści nauczania. Ona jest konieczna przede wszystkim po to, aby móc w większym zakresie indywidualnie rozwijać każdego ucznia, ograniczyć pośpiech. Kluczowym w edukacji jest kształtowanie określonych kompetencji, i aby efektywnie działać w tym zakresie nauczyciel musi mieć więcej swobody w doborze treści kształcenia. One są środkiem a nie celem nauczania. A obecny system umieszcza je w centrum zainteresowania szkoły, a nauczyciela sprowadza do realizatora szkolnego programu. Wyjątkowo niekorzystnie pod tym względem przedstawia się edukacja muzyczna. Na rozbudowane w treści programy przeznaczanych jest bardzo mało czasu. Problemem edukacji muzycznej jest realizowany od szeregu lat model zrównoważonego, ekstensywnego nauczania. Powoduje to, iż nagromadzone treści pobieżnie realizujemy. Przyjęliśmy kilkadziesiąt lat temu, że do zrozumienia muzyki prowadzić może wiele dróg i że powinno się je wszystkie wykorzystywać. Tak też od lat siedemdziesiątych równoprawne w szkole stały różne formy kontaktu z muzyką. Uczniowie - przynajmniej w założeniach, bo z realizacją różnie bywa - do dnia dzisiejszego mają na lekcjach śpiewać, grać na instrumentach, słuchać muzyki (poznawać dzieła muzyczne), w granicach swoich możliwości tworzyć ją, realizować zadania związane z ruchem przy muzyce (rytmiczne i taneczne), zdobywać wiedzę z teorii muzyki, w tym uczyć się notacji muzycznej oraz poznawać zagadnienia z historii i kultury muzyki.

Można mieć wątpliwości czy takie nauczanie jest efektywne. Szereg badań pokazuje iż rezultaty tak prowadzonej edukacji nie są najlepsze (por. Białkowski, Grusiewicz 2009a, s. 175-190; Białkowski, Grusiewicz 2009b, s. 191-208; Białkowski, Grusiewicz, Michalak 2010; Weiner 2010; Grusiewicz 2011; Bonna 2016). W czasach współczesnych model edukacji zrównoważonej przynajmniej w zakresie muzyki, ale myślę, że i innych sztuk nie jest najwłaściwszym. W kontaktach ze sztuką - co zresztą wielokrotnie podkreślała Maria Przychodzińska - jakość tych kontaktów jest ważna. One powinny sprawiać uczniom jak nie radość, wzruszenie, to na pewno satysfakcję, którą możemy doznać wskutek dobrze wykonanych zadań, z tego że potrafimy, rozumiemy, wspólnie działamy. 
W edukacji muzycznej powinniśmy skupiać się na wybranych treściach, należy odejść od traktowania wszystkich elementów i treści muzycznych za tak samo ważne. Tu szczególnie, i to $\mathrm{w}$ znacznym zakresie, należałoby zredukować treści związane $\mathbf{z}$ wiedzą muzyczną. Systematyzacja tej wiedzy z teorii i kultury muzycznej jest celowa w szkolnictwie artystycznym, w edukacji powszechnej wystarczy jej tyle, ile jest konieczne dla zrozumienia muzyki, świadomego jej wykonywania oraz zainteresowania dziełami muzycznymi.

Celowym wydaje mi się oparcie edukacji muzycznej w sposób szczególny na dwóch formach, na wykonywaniu muzyki oraz jej słuchaniu. Obecnym standardem jest łączenie w jednej jednostce lekcyjnej różnych form kontaktu z muzyką, w tym wykonywania muzyki z jej słuchaniem. I oczywiście można tak czynić i te dwie formy można i należy łączyć, w tym słuchanie można wspierać wykonywaniem, czyli nawiązywać do tzw. aktywnego słuchania muzyki. Każdą czynność muzyczną można obudowywać innymi działaniami, np. wykonywanie wspierać elementami twórczości, ruchu, body percussion, łączyć muzykę z innymi dziedzinami sztuk. Warto jednak zwrócić uwagę, że każda forma kontaktu z muzyką jest dość specyficzna, odrębna, to są niezależne od siebie czynności muzyczne, wymagają innej literatury, innego podejścia, innej organizacji zajęć, wręcz innej przestrzeni i zaplecza dydaktycznego. I równie dobrze każda z tych form może - nie tylko na zajęciach pozaszkolnych i pozalekcyjnych, ale w ramach obowiązkowych zajęć - występować odrębnie. Wcale nie muszą być przywiązane do siebie, złączone w spójne jednostki tematyczne.

Słuchanie muzyki w szkole wygląda wyjątkowo niekorzystnie. Szkoły nie posiadają odpowiedniego zaplecza i sprzyjających warunków do zapoznawania z wybitnymi dziełami. Szkolne sale, sprzęt do odtwarzania, jak i same nagrania w zasadzie uniemożliwiają podjęcie starań, aby kontakt $\mathrm{z}$ muzyką prowadził do doznań, przeżyć, do głębszego zainteresowania przedmiotem. Żeby było to możliwe słuchaniu należałoby nadawać formy istotnych wydarzeń, kreacji. I tu szkoła powinna spełniać podstawowe wymagania współczesności, w tym przekaz kierowany do uczniów należy uczynić atrakcyjnym. Sala do słuchania, choć trochę musi być „przyjazna”, zachęcać do przebywania, powinna ona ułatwiać oderwanie się od codziennych wydarzeń i spraw, i skupienie się na z natury abstrakcyjnych dźwiękach. I to co najważniejsze muzyka prezentowana uczniom musi być na najwyższym poziomie artystycznym.

W tym obszarze można i należy korzystać ze współczesnych mediów, chociażby z YouTube. W dzisiejszej praktyce takie sytuacje są sporadyczne. W przybliżaniu uczniom muzyki wkładamy pewien wysiłek, ale te działania nie są skuteczne. Uczniowie są zapoznawani z utworami muzycznymi w taki sam sposób, w jaki na języku polskim poznają literaturę. Staramy się tłumaczyć, objaśniać idee dzieła i jego konstrukcję, zwracać uwagę na pewne elementy, przybliżać postać kompo- 
zytora i jego stylu. Na języku polskim takie podejście ma sens, jako że wymiar intelektualnego poznania literatury bezpośrednio przekłada się na kształtowanie postaw, systemu wartości, ocen zachowań, łączy się też z kształtowaniem erudycji, umiejętności posługiwania się językiem w mowie i piśmie. Na muzyce przybliżanie słowem dzieł muzycznych może zadziałać tylko pod warunkiem, że jego efektem będzie doświadczenie muzyki z możliwością jej głębokiego przeżycia. Obecną praktyką jest też prezentowanie fragmentów dzieł, lub ich uproszczonych opracowań. Tego typu działania mogą być, ale tylko elementem przygotowującym do właściwych spotkań z muzyką artystyczną, same w sobie większej wartości nie mają. W słuchaniu muzyki nie powinno być miejsca na uproszczenia, na prezentację dzieł w łatwych, „zastępczych” opracowaniach.

Problemem też jest literatura muzyczna przeznaczona do słuchania. Szlachetne zamiary przybliżenia najważniejszego dorobku kultury europejskiej nie sprawdzają się. Chronologiczne czy też problemowe ujęcia tematów powodują że muzyka jest tylko przykładem jakiegoś zagadnienia. A wielość i pobieżność prezentacji nie skłania do poznawania i dostrzegania różnic gatunkowych i stylistycznych. A trzeba wyraźnie stwierdzić, że piękno muzyki tkwi w niuansach, które trzeba dostrzec. I oczywiście ważnym jest rozróżnienie stylistyczne między Mozartem a Chopinem, ale równie ważne wydaje się uchwycenie różnic we współczesnych działach muzycznych, odróżnianie tego co wartościowe od tego co kiczowate, artystycznie dopracowane od popularnej chałtury.

Pewien problemem dla współczesnego słuchacza stworzyła awangarda muzyczna oparta na dodekafonii. Ona spowodowała odwrócenie się ludzi od muzyki artystycznej, w skali masowej powszechne stało się przekonanie, że jest ona trudna, nieatrakcyjna i niezrozumiała. Postmodernizm przywrócił tonalność również i muzyce artystycznej, ale postaw ludzkich nie zmienił. Musimy na nowo nauczyć ludzi słuchać współczesnej muzyki artystycznej. Roger Scruton problem ten definiuje następująco:

Nowa publiczność znajduje przystępne doświadczenie „wyższej” kultury muzycznej również w twórczości Góreckiego i Tavenera. Jest to bowiem muzyka poważna, zawierająca obietnicę wyzwolenia od wyalienowanego świata kultury popularnej. Jednocześnie jest skomponowana tak jak muzyka pop, z monodycznym śpiewem na tle nierozpisanych na głosy akordów. Można odnieść wrażenie, że muzyka poważna musi zacząć od początku, od pierwszych niepewnych kroków tonalności, aby odzyskać ponowoczesne ucho (Scruton 2010, s. 115-116).

Podstawą, codziennością edukacji muzycznej, powinno być wokalne i instrumentalne wykonywanie muzyki - zawsze świadome, kreatywne i twórcze. I jeżeli ono takie jest, to w każdej formie uczy elementarnej muzykalności, zrozumienia 
muzyki, jest to najpełniejsza forma poznawania muzyki. Wielkie walory wychowawcze i społeczne mają zarówno indywidualne ćwiczenia, jak i zespołowe muzykowanie. Można i należy muzykować na tradycyjnych instrumentach, ale trzeba też promować i wspierać takie przedsięwzięcia, jak boomwhacker (bum bum rurki), body percussion, instrumenty elektroniczne, $\mathrm{w}$ tym te dostępne w aplikacjach na smartfony i tablety, czy też instrumenty wirtualne i przestrzenne.

Edukacja muzyczna powinna opierać się na aktywnych formach obcowania z muzyką, na emocjach i doświadczaniu muzyki. Pewnym wzorcem dla zajęć szkolnych mogłyby być rozwijane w instytucjach kultury czy przez organizacje społeczne różne formy amatorskiego uprawiania muzyki, programy i projekty, takie jak chociażby Śpiewająca Polska czy niedawno uruchomione Grajmy w Szkole czy Pracowania Muzyczna Casio. Oczywiście, aktywne uprawianie muzyki należy dostosować do warunków szkolnych, do sytuacji pewnej obligatoryjności. Kierując ofertę do wszystkich uczniów, trzeba uwzględniać ich potrzeby i możliwości, stąd też niezmiernie ważne jest, aby była ona różnorodna i nakierowana na cele związane z ogólnym rozwojem muzycznym i społecznym uczniów. Trudne do realizacji, ale wskazane wydaje się rozwijanie zajęć adresowanych do całej społeczności szkolnej w formach pozaklasowych i pozalekcyjnych. Warto tu też pomyśleć o indywidualnych (w niewielkich grupach) formach nauki gry na instrumentach.

Zespoły muzyczne przy szkołach ogólnokształcących, powszechne w Ameryce, w Niemczech, w wielu krajach, przyczyniają się do lepszego wychowania młodzieży - potwierdziły to badania. Muzykowanie zespołowe nie tylko uwrażliwia, ale też uczy porządku, samodyscypliny, konsekwencji (Rakowski 2018, s. 66)

Wspólne muzykowanie z dziećmi wydaje się być najatrakcyjniejszym sposobem, by je do muzyki zachęcić.

\section{PODSUMOWANIE}

Przedstawiając różne, naszym zdaniem konieczne przeobrażenia w powszechnej edukacji muzycznej, warto wyraźnie podkreślić, że w nauczaniu każdy kontakt z muzyką powinien być świadomy i kreatywny - każdy inny dla wychowywania człowieka niewielkie ma znaczenie. Istotą edukacji powinny być aktywne formy obcowania z muzyką oparte na emocjach i kreatywnym i twórczym doświadczaniu muzyki. Dzierżymir Jankowski pisał na ten temat:

Edukacja kulturalna powinna promować i umożliwić jednostce twórczość i autoedukację, ale też chronić ją przed zagubieniem w gąszczu nachalnych ofert 
kultury popularnej i rynku, wzbudzać wysokie aspiracje kulturalne i sprzyjać sublimacji aktywności kulturalnej (Jankowski 2006, s. 72).

W kontekście tych rozważań warto też przytoczyć słowa Jeana Jacques Rousseau, którego czasami traktujemy jako utopistę, nieracjonalnego marzyciela, ale który na edukację muzyczną wywarł ogramy, pozytywny wpływ. W Emilu, czyli o wychowaniu, ponad 200 lat temu, napisał między innymi: „ucz jej [muzyki, dop. M.G], jak chcesz, byleby była zawsze rozrywką tylko" (Rousseau 1955, s. 176) - i nie chodzi tu o zabawę, ale o pozytywne emocje i doznania. Musimy doprowadzić do tego, aby szkolna edukacja muzyczna była lubiana i oczekiwana przez uczniów.

I wracając do tezy o konieczności daleko idących przeobrażeń w edukacji, nie tylko w obszarze muzyki, sztuki i kultury, ale całościowych, na zakończenie przytaczamy słowa Kena Robinsona wygłoszone podczas jednego z wykładów TED ${ }^{3}$

Wszystkie systemy edukacji na świecie są teraz ulepszane. Ale to nie wystarczy. Ulepszanie już nie pomaga. Potrzebujemy [...] nie ewolucji tego systemu a rewolucji. Edukacja musi być przekształcona w coś zupełnie innego.

Dodałbym do tego, że póki nie wymyślimy szkoły na nowo, zmieniajmy tę którą mamy, a że jest to możliwe i w naszej rzeczywistości pokazuje szkoła w Konstancinie-Jeziornej.

\section{LITERATURA}

Badanie segmentacyjne uczestników kultury. Prezentacja wyników badania ilościowego. 2016, PDF, Warszawa, Smartscope, [pozyskano z: https://nck.pl/upload/attachments/319000/Segmentacja-uczestnikow-kultury-raport.pdf]

Bagby P., 1975, Kultura i historia. Prolegomena do porównawczego badania cywilizacji. Warszawa, PIW.

Bagiński K., Najlepsza szkoła na świecie jest... pod Warszawa. Nie maja ławek, a o podręcznikach nie styszeli, opublikowano: http://innpoland.pl/140189,najlepszaszkola-na-swiecie-jest-pod-warszawa-nie-maja-lawe-a-o-podrecznikach-nie-slyszeli [dostęp: 26.06.2018].

Barber B. R., 2013, Dżihad kontra McŚwiat. Warszawa, Wydawnictwo Muza.

Bauman Z., 2006, Czy istnieje postmodernistyczna socjologia? W: A. Jasińska-Kania, et al. (wybór i oprac.), Wspótczesne teorie socjologiczne 2. Warszawa, Wydawnictwo Naukowe Scholar, 789-802.

Bauman Z., 2008, Płynna nowoczesność. Kraków, Wydawnictwo Literackie.

${ }^{3}$ Robinson, Zrewolucjonizujmy nauczanie!, wykład TED, https://www.ted.com/talks/sir_ken_robinson_bring_on_the_revolution?language=pl [dostęp: 4.09.2018]. 
Bendyk E., et. al., 2007, Kultura 2.0. Wyzwania cyfrowej przyszłości. Warszawa, Polskie Wydawnictwo Audiowizualne.

Białkowski A., 2000, Polska koncepcja powszechnego wychowania muzycznego a wyzwania współczesności. „Wychowanie Muzyczne w Szkole”, nr 4 (221), 124-131.

Białkowski A., 2001, Powszechna edukacja muzyczna. Współczesne zagrożenia i dylematy. „Wychowanie Muzyczne w Szkole”, nr 4 (226), 179-184.

Białkowski A., Grusiewicz M., 2009a, Kompetencje muzyczne uczniów szkół podstawowych. W: M. Zalewska-Pawlak (red.), Sztuka wobec zakresów wolności człowieka liberalnego. Pedagogiczne rozważania i doświadczenia. Łódź, Wydawnictwo UŁ, 175-190.

Białkowski A., Grusiewicz M., 2009b, Kompetencje muzyczne uczniów gimnazjum. W: M. Zalewska-Pawlak (red.), Sztuka wobec zakresów wolności człowieka liberalnego. Pedagogiczne rozważania i doświadczenia. Łódź, Wydawnictwo UŁ, 191-208.

Białkowski A, Grusiewicz M., Michalak M., 2010, Edukacja muzyczna w Polsce. Diagnozy, debaty, aspiracje. Warszawa, Fundacja Muzyka jest dla wszystkich.

Bonna B., 2016, Zdolności i kompetencje muzyczne uczniów w młodszym wieku szkolnym. Bydgoszcz, Wydawnictwo UKW.

Dziamski G., 2017, Sztuka wysoka i niska. „Dyskurs. Pismo Naukowo-Artystyczne ASP we Wrocławiu", nr 23, 7-26.

Fatyga B., 2009, PDF, Jakiej kultury Polacy potrzebuja i czy edukacja kulturalna im ja zapewnia. Raport o problemach edukacji kulturalnej w Polsce dla Ministerstwa Kultury i Dziedzictwa Narodowego. Warszawa, MKiDN, [pozyskano z:

https://nck.pl/badania/raporty/jakiej-kultury-polacy-potrzebuja-i-czy-edukacja-kulturalna-im-ja-zapewnia-raport-o-]

Fatyga B., Drozdowski R., et. al., 2014, PDF, Praktyki kulturalne Polaków. Toruń, Wydawnictwo Naukowe Uniwersytetu Mikołaja Kopernika, [pozyskano z: https:// nck.pl/badania/raporty/praktyki-kulturalne-polakow].

Gajda J., 2006, Pedagogika kultury w zarysie. Kraków, WSP ZNP, Impuls.

Gajda J., 2008, Antropologia kulturowa. Kultura obyczajowa początku XXI wieku. Kraków, Impuls.

Grusiewicz M., 2011, Kompetencje muzyczne uczniów ogólnokształcących szkół podstawowych i gimnazjów. Lublin, Stowarzyszenie Nauczycieli Muzyki.

Grusiewicz M., 2015, Kongres w prawdziwie światowym stylu. Powiew zmian i innowacji w oświacie, „Wychowanie Muzyczne” nr 5 (297), 13-25.

Grusiewicz M., 2017a, Zapomniane przeżycie estetyczne. W: B. Pazur (red.), Non omnis moriar. Na tropach piękna. Lublin, Wydawnictwo Muzyczne Polihymnia, 27-44.

Grusiewicz M., 2017b, Co dalej z edukacja muzyczną? „Wychowanie Muzyczne” nr 5 (307), 4-9. 
Grusiewicz M., 2018, Muzyka w edukacji przyszłości, „Studia z Pedagogiki Muzycznej", nr 1, 13-24.

Harnoncourt N,. 1995, Muzyka mowa dźwięków. Warszawa, Fundacja Ruch Muzyczny. Konaszkiewicz Z., 1995, Badania odbiorców muzyki - wnioski dla wychowania muzycznego i muzykoterapii. W: A. Białkowski (red.), Wychowanie muzyczne. Stan badań a praktyka edukacyjna. Lublin, Wydawnictwo UMCS, 183-188.

Leszczyński P., Kultura masowa a kultura popularna, Po wielu latach opozycja kultury niskiej i kultury wysokiej odchodzi do lamusa. W takim razie co nam pozostaje?, opublikowano: https://www.wywrota.pl/sztuka/16392-kultura-masowa-a-kulturapopularna.html.

Jankowski D., 2006, Pedagogika kultury. Studia i koncepcja. Kraków, Oficyna Wydawnicza Impuls.

Jedlewska B., 2009, Współczesne oblicze kultury - aktualny wymiar uczestnictwa w kulturze. „Wychowanie Muzyczne”, nr 5 (267), 13-18.

McLuhan M., 1962, The Gutenberg Galaxy. Toronto, University of Toronto Press.

McLuhan M., 2017, Galaktyka Gutenberga. Warszawa, Narodowe Centrum Kultury. Majerek B., 2018, Niepewność w społeczeństwie współczesnym. Studium socjopedagogiczne. Kraków, Oficyna Wydawnicza Impuls.

Moraczewski K., 2007, Sztuka muzyczna jako dziedzina kultury. Próba analizy kulturowego funkcjonowania zachodnioeuropejskiej muzyki artystycznej, Poznań, Wydawnictwo Naukowe UAM.

Moraczewski K., 2017, Po co nam muzyka klasyczna? wykład wygłoszony podczas I Ogólnopolskiej Konferencji dla Nauczycieli Muzyki Szkół Powszechnych. „Muzyka klasyczna w powszechnej edukacji muzycznej”, Radziejowice 8.12.2017.

Postman N., 2004, Technopol. Triumf techniki nad kultura. Warszawa, Wydawnictwo Muza.

Postman N., 2006, Zabawić się na śmierć. Dyskurs publiczny w epoce show-businessu. Warszawa, Wydawnictwo Muza.

Przychodzińska M., 2011a, Powszechne wychowanie muzyczne 1960-1990. Między koncepcja a realizacja (1). „Wychowanie Muzyczne”, nr 3 (275), 4-14.

Przychodzińska M., 2011b, Powszechne wychowanie muzyczne 1960-1990. Między koncepcja a realizacją (2). „Wychowanie Muzyczne”, nr 4 (276), 4-16.

Rakowski A., 2018, Jest wiele do zrobienia, „Wychowanie Muzyczne”, nr 2 (309), 64-70.

Robinson K., Aronica L., 2015a, Kreatywne szkoły. Oddolna rewolucja, która zmienia edukację. Kraków, Wydawnictwo Element.

Robinson K., Zmiana paradygmatu edukacji, film dostępny na: https://www.youtube. com/watch?v=_wxcXd5Cnv8 [dostęp: 4.09.2018]. 
Robinson K., Zrewolucjonizujmy nauczanie!, wykład TED, film dostępny na: https:// www.ted.com/talks/sir_ken_robinson_bring_on_the_revolution?language $=\mathrm{pl}$ [dostęp: 4.09.2018].

Rousseau J. J., 1955, Emil, czyli o wychowaniu. T. 1. Wrocław, Wyd. PAN.

Scruton R., 2010, Kultura jest ważna. Wiara i uczucie w osaczonym świecie. Poznań, Zysk i S-ka.

Smoleńska-Zielińska B., 2018, Ucieczka czy trwanie? Cz. I. Edukacja muzyczna w dobie plynnej kultury. „Wychowanie Muzyczne”, nr 2 (309), 4-12.

Spengler O., 1921, The Decline of the West. London.

Toeplitz K. T.,1075, Kultura w stylu blue jeans. Warszawa, PIW.

Weiner A., 2010, Kompetencje muzyczne dzieci w młodszym wieku szkolnym. Determinanty, zależności, perspektywy rozwoju. Lublin, UMCS.

\title{
MUSIC EDUCATION - HEADING FOR CONTEMPORARY CULTURE
}

\begin{abstract}
The paper addresses questions essential for the education system: whether it offers up to date education, whether schools keep pace with the social reality, scientific world, the world of art and culture, and in particular, whether it draws attention to the need to comply with changes taking place in contemporary culture in designing the music education curricula. Presented theses and conclusions are based on the belief that cultural transformation we have been witnessing is a persistent phenomenon. It has taken place primarily through modern technologies and media, therefore schools and music education as a subject must take this fact into account, both in terms of ideas, curricula and daily practice. The paper has two parts. The former, based on analyses in the field of theory and sociology of culture, as well ascultural anthropology and education, discusses components appearing to be of key importance for understanding the present-day status of culture and for designing new solutions in universal music education; the author is trying to challenge some stereotypes and prejudice in thinking about contemporary musical culture. Analysis of these factors has provided the starting point for the latter part, outlining changes necessary in music education in order to make it satisfy important human needs and achieve essential objectives it was credited.
\end{abstract}

Keywords: contemporary culture, art, musical arts, education, music education. 